\title{
Interview with director Jayan K. Cherian
}

\begin{abstract}
In this interview with Judith Misrahi-Barak and Nicole Thiara, Jayan K. Cherian discusses his work as an independent filmmaker in India and the USA, his artistic and political commitment, and the challenges he has faced with the Central Board of Film Certification in India after the release of his first feature film Papilio Buddha (2013), which focuses on Dalit land struggles in Kerala, and again with his second feature film KaBodyscapes (2016). The interview explores how holding a dual status as an American citizen and an Overseas Citizen of India makes his situation more complex because it offers him both the freedom and constraints of being a permanent outsider. The discussion of Papilio Buddha and its representation of the Dalit land struggle is the focus of the interview. He also speaks about his intended audience(s) and the way he works on location with his crews. Since Cherian is a poet and a writer as well as a filmmaker, he explains his choices for specific media, in the particular contexts in which he positions himself.
\end{abstract}

\section{Keywords}

Jayan K. Cherian, Dalit, Kerala, independent Indian cinema, Central Board of Film Certification (CBFC)

Jayan K. Cherian was born in Kerala, India. He obtained a BA in Film and Creative Writing with Honours from Hunter College, and an MFA in filmmaking from the City College of New York. He has made several documentaries and narrative shorts, among which perhaps the most significant is Shape of the Shapeless (2010). Further details can be found at http://jayankc.com. Papilio Buddha (2013) was his debut feature film. His second feature film, KaBodyscapes, also set in Kerala, was released in 2016.

His films have been screened at the Berlin International Film Festival, BFI London Lesbian and Gay Film Festival, Montreal World Film Festival, and other major festivals around the globe. He has won several awards, including the Kerala State Film Special Jury Award for Best Direction, Kerala Film Critics Association Award for Best Debut Director, the Silver Conch Award at Mumbai International Documentary Film (MIFF), the Silver Jury Prize at San Francisco Shorts, the Directors' Choice Award in the Black Maria Film Festival, and Honourable Mentions at Athens International Film and Video Festival. He has also published four award-winning volumes of poetry in Malayalam. 
In this interview with Judith Misrahi-Barak and Nicole Thiara, Jayan K. Cherian discusses his work in India and in the USA, and the difficulties in belonging to these two countries at once. He speaks about his intended audience(s), and the way he works on location with his crews. Since he is also a poet and a writer as well as being a filmmaker, he explains his choices for specific media, in the particular contexts in which he positions himself. What emerges through this interview is Cherian's artistic and political commitment to oppose any form of political and social oppression, heteronormativity, homophobia, or misogyny. His clear positioning against caste and gender discrimination is captured on screen in a very distinct way. The creation of a cinematic style that is at once poetic and political, merging fiction and documentary filming, offers a complementary perspective to the one expressed on the page by the Dalit writers and poets who are at the centre of this special issue, but one that is just as ruthlessly critical.

At a time when India is still showcasing itself on the global stage as "the biggest democracy in the world", while implementing political, social, religious, and gender discrimination on its soil, it is important to remember that filmmaking is still ruled by the 1952 Cinematography Act, with the Central Board of Film Certification functioning in actual fact as a censor board. In the context of recent Dalit struggles and political oppression in India, artistic creation, in word and in image, has an essential political and social role to play.

\section{Interview with director Jayan K. Cherian}

\section{by Judith Misrahi-Barak and Nicole Thiara}

JMB: You were born in India and grew up in Kerala, but have been living in the USA for more than 25 years, and you have been making short films and feature films since 2006. Some of your short films are set outside India, while the two feature films you directed are set in Kerala. Your films have won prizes at many international festivals (Berlin, London, Montreal) and in the Indian context, too. How do you navigate this dual scene, working and living in the US, shooting and doing the post-production of your films in India? As an Indian film director with American citizenship you hold an American passport and enjoy OCI [Overseas Citizen of India] status. Would it be wrong to say that, through filmmaking and your work in general, you have obtained the kind of dual citizenship that you could not obtain through a legal process?

JC: $\quad$ Yes, I have been living in the United States for almost 27 years, and travelling back and forth to India continuously for the past six years, because of the latest two projects, Papilio Buddha and KaBodyscapes, being shot and edited in India. Both are Indian stories, and these narratives are set in Kerala, where I spent my formative years. These stories are close to me, and it is a subject I care about. I am probably not American enough to be called an American filmmaker. At the same time the Indian film industry doesn't consider me as an Indian filmmaker because of my US passport; they 
disqualified Papilio Buddha from being part of the competition in the Indian Panorama at the Indian International Film Festival. It makes me a permanent outsider, who doesn't belong anywhere. It is a strength as a storyteller: I can look at my own culture as an outsider, and more critically so. So yes, you can say that I have a "dual citizenship" that is outside of both countries' law.

JMB: This dual/double situation must have given rise to a certain number of challenges but also, surely, to finding solutions. Looking back at the past 25 years and at your present situation, what is your take on this complex combination of constraint and freedom?

JC: Yes, this dual situation seems to have helped me to be more objective about my own culture, and to critically approach my traditions and notions. There is indeed something liberating in it. Practically, however, it has meant running into a lot of difficulties with the current nationalist government in India, and with the diaspora community in the USA, since the majority are nationalistic and proud of their heritage. When you critique it, you make a lot of enemies. Yes, it is a complex combination of freedom and constraint.

JMB: Papilio Buddha was censored by the Indian censor boards, and still cannot officially be shown in India in its full version. Can you tell us something of the conditions the film was first imagined in, then cast and shot, and distributed?

JC: $\quad$ Papilio Buddha was inspired by several events that happened in various Dalit communities in Kerala, including their struggle for land in places such as Chengara, Meppadi, and Muthanga, and its effect on the Dalit population and the environment. The Dalit colonies in Kerala are the best examples of social segregation. These colonies have historically served as the primary sources of muscle power for traditional parties including the Communists; naturally, they see Dalit activism as a threat to their existence. The oppressions inflicted upon the DHRM [Dalit Human Rights Movement] activists between 2007 and 2010 by the police and the political parties are unimaginable, and it was getting out of control. The mainstream media and middleclass intellectuals turned a blind eye towards it because Dalit movements like the DHRM were framed as terrorist organizations then. This was the political situation when I started to write the film. I interviewed several victims of caste atrocities and generated a screenplay out of it, and cast several activists as characters in the movie.

I shot the film with a plan to distribute it in Kerala. But we need the censor board's certificate to distribute the film. So we approached the CBFC (Central Board of Film Certification). The regional censor board in Thiruvananthapuram gave us a certificate of refusal, which states that the movie is not certifiable, with or without cuts. We appealed to the revision committee, which was a 12-member committee chaired by Shaji N. Karunan; they suggested several changes, around 56 cuts, mutes, and blurrings to the film to get an "A" certificate (Adults only). We could not accept those suggestions, so we appealed to the FCAT (Film Certification Tribunal) 
in Delhi. After several months of deliberations through various bodies of censorship hierarchy, the FCAT issued the "A" certificate, with the condition that we muted several dialogues, including the reference to Dr. Ambedkar's quote on Gandhi's fasting at Yervada jail, which led to the "Poona Pact". As you know, on 16 August 1932, the British prime minister Ramsay Macdonald granted separate electorates in British India for the Forward Caste, Lower Caste, Muslims, Buddhists, Sikhs, Indian Christians, Anglo-Indians, Europeans, and Dalits. Gandhi opposed the separate constituency for Dalits, and he declared a fast unto death to force the Dalit leaders to give up their privilege. This notorious fast led to the "Poona Pact", which was an agreement between Gandhi and Ambedkar in which Gandhi forced Ambedkar to give up the separate constituency for Dalits in the election. Ambedkar wrote about Gandhi's fasting in his book What Congress and Gandhi Have Done to the Untouchables: "There was nothing noble in the fast. It was a foul and filthy act. The fast was not for the benefit of the Untouchables. It was against them and was the worst form of coercion against a helpless people to give up the constitutional safeguards [which had been awarded to them]" (1945: n.p.). One of the characters in Papilio Buddha refers to this moment in history, and FCAT wanted us to delete it from the scene. We were also required to blur the scene where the Dalit protesters burn an effigy of Gandhi.

Meanwhile, the film was selected for one of our prestigious film festivals, IFFK (International Film Festival of Kerala). The film was eventually removed from the selection list due to some political pressure. So we arranged a private screening in an auditorium near the festival venue, but just before the screening the police burst into the theatre and shut it down. The audience did a protest march to the festival venue, but nothing happened. It is still illegal to show the original version of Papilio Buddha in India.

People may wonder how it is possible for the government to suppress a work of art in a democratic society like India. The CBFC is working under the Ministry of Information and Broadcasting in Delhi, under the guidelines of a law called the Indian Cinematography Act of 1952, which enables them to make these kinds of editorial interventions into a work of art. This act is the reincarnation of a colonial law, The Indian Cinematography Act of 1918, which was framed by the British and was based on the idea that Indians were unable to choose what is right for them to watch, so their masters should decide for them. The same patronizing colonial logic is still at work behind several post-1947 laws in India. The idea of a government body censoring a work of art in itself is ridiculous in 2016, and it is a shame that a democratic country like India should still have state instruments that curtail the freedom of artistic expression.

JMB: Papilio Buddha very much brings into focus the character of Kallen Pokkudan and his struggle. For people outside India who would not know him, can you introduce him and the impact he had in Kerala, and maybe explain the relationship between the film character and the real-life figure? 
Also, what link can we establish between the film and Pokkudan's two autobiographies published in Malayalam? Have they had any influence in the making of the film?

JC: Kallen Pokkudan was a prominent Dalit rights and environmental activist in Kerala. Born in 1937 as a member of a Dalit family, who were traditional agrarian slaves owned by upper-caste landlords, Pokkudan went to school up to the second grade and was forced to work in paddy fields to survive. In his teens, he ran away from the fields and became an activist in the Communist Party of India; he participated in the early peasant revolts in Kannur district. He was accused of killing a rogue landlord and was jailed for some time. Later, he left the Communist Party, due to some ideological conflict with the party and the caste discrimination he suffered as a "Dalit comrade" within the party. After his split with the party, Pokkudan spent his time in environmental protection activities, focusing on the protection of the mangrove forests of Kerala. He embarked on a mission to plant mangroves across the coastal waters of Kerala, and is reported to have planted over one lakh of mangrove plants in the state. He founded the Mangrove School and conducted over 500 classes in various parts of the state in an attempt to educate the masses about the ecological importance of mangroves. Pokkudan wrote a few books, including Kandal Inangal (2015; Mangrove Varieties), as well as two autobiographies, Kandalkkadukalil Ente Jeevitham (2002; My Life in the Mangrove Forests), and Ente Rashtreeya Jeevitham (2010; My Political Life).

One of the central characters in Papilio Buddha, Kariyan, who is played by Kallen Pokkudan himself, is inspired by his life: though the character is fictional, he is nevertheless very close to Pokkudan's life, and my writing of that character was greatly influenced by his autobiographies and interviews. Working with Kallen Pokkudan was a fascinating experience for me as a filmmaker. Unfortunately he passed away on 27 September 2015. He was a great human being and a relentless fighter for his cause.

JMB: After Pokkudan's death, and the death of the leader of the DHRM, Anil Kumar Aka Thathu Annan, on 18 July 2015, the film is to be seen even more as a tribute to their work, isn't it? Are you optimistic about the impact and momentum the film has created?

JC: $\quad$ Yes, the film is a tribute to their work. Thathu Annan, the founder of the DHRM, was a close friend and helped me a lot in the research and writing of Papilio Buddha. He and other DHRM activists went through horrific torture in police custody by Kerala police and other casteist entities in Kerala. The police atrocities committed against DHRM activists during 2007-2010 were the immediate inspiration to make Papilio Buddha. The DHRM is a much more mainstream Dalit organization now, and it has become a political party and participates in elections. The DHRM is thriving now under the brilliant leadership of Saleena Prakkanam, one of the prominent leaders of the legendary Chengara Land struggle, and the current chairperson of the movement. 
NT: Papilio Buddha is a film that criticizes the environmental devastation of this part of India and presents this destruction of nature as sanctioned by the state. It is interesting how the film represents the Dalit characters as aligned with nature. How are your critique of the state and your representation of the Dalit land struggle related?

JC: $\quad$ Papilio Buddha was shot in the Western Ghats of India, the last rainforest left in India and one of the most biologically diverse areas in the world; the Papilio Buddha is an endangered species of butterflies that is endemic to the region. The Western Ghats is a $1600 \mathrm{~km}$-long mountain chain, which has forests older than in the Himalayas, stretching between Gujarat, Maharashtra, Goa, Karnataka, Tamil Nadu, and Kerala, and it has been listed as a world natural heritage site by UNESCO. But now, this biological and environmental "hot spot" is devastated by severe deforestation, land grabbing by quarry mafia, and other corporate forces. In Papilio Buddha, we captured visually the horror of this ecocide in a region where Adivasis and the Dalit population were leading an environmentally-friendly life. These were people whose living depended on the forest. The state-sanctioned deforestation and ecocide goes hand in hand with the genocide of the people who were displaced from their habitat. Activists like Kallen Pokkudan saw this coming. They were ready to fight and put up resistance by putting their lives on the line where the state had become an agent wreaking havoc and destruction. The struggle for the butterflies and the struggle for the people have become one.

NT: Papilio Buddha is a film whose cinematography is experimental and metaphorical. Can you tell us more about the cinematographic techniques that you employed in this film?

JC: The director of photography of Papilio Buddha was M. J. Radhakrishnan, one of the senior cinematographers working in Indian cinema. We shot with a RED camera, in 4K, with prime lenses; for outdoor scenes we used available natural lights, and minimalistic motivational lighting for indoor and night scenes. Nature is a major character in the film, so we used long shots with wide lenses to capture the entire ecosystem and the diminutive size of the humans against the vastness of nature. We used thick filters to control light and colour. The colour is an important storytelling tool in Papilio Buddha; we graded it in a black-yellowish colour to achieve a beige look, and to capture the bleak reality of the plight of the displaced. We had an amazing sound team from Pune Film Institute led by S. Radhakrishnan and Ajayan Adat, who devoted themselves to capturing the unique soundscape of the Western Ghats.

NT: The sex scene between Shankara and Manjusri refers to Buddhist tantric practices. Could you tell us what this scene represents? Is it meant to shock Dalit Buddhist audiences?

JC: "Manjusri", the name of the character in the film, is not accidental. Manjusri is a Buddhist deity, who is often depicted as a Buddha holding a sword in one hand and a book, Prajnaparamita, in the other hand. In the film Shankara 
and Manjusri are depicted sitting in Yab-Yum position; Yab-Yum is a common symbol in the tantric tradition of Buddhist art of India, Bhutan, Nepal, and Tibet. It represents the primordial union of wisdom and compassion, depicted as a male deity in sexual union with his female consort. The male figure represents compassion and skilful "means" while the female partner represents insight. In tantric tradition sexual intercourse becomes a prayer, an initiation, and a spiritual act. In Kerala, we had a long tradition of Buddhism before the brahminical religion now known as "Hinduism" conquered us and captured the temples; several Hindu temples and deities in Kerala were originally Buddhist, then were turned into Hindu temples. By designing this scene in the film I was trying to evoke our long forgotten tantric tradition, and its remembrance is in itself a political act, in the current prudish cultural situation of Kerala. No, it is not meant to provoke any new evangelical Buddhists.

JMB: KaBodyscapes does not focus on the Dalit struggle but on another kind of struggle that Western audiences may not be familiar with, or at least that would not be in line with the image they have of India (the biggest, fastest growing democracy in the world, the emerging country, and so on). Many people don't know about censor boards in India, for example, and nor do they know about homosexuality being illegal. Many people know about discrimination against women in India, but not necessarily the extent of the oppression. KaBodyscapes has also been refused a certificate by the censor boards in India, probably because it is a film precisely about censorship in all kinds of domains. At the time of this interview, it has been screened in festivals in London (BFI Flare), Turino (Italy), and New York (New York Indian Film Festival). Can you say a few words about this second feature film and explain what you wanted to achieve?

JC: KaBodyscapes is the story of three young people: Haris, a gay painter; Vishnu, a rural kabaddi player; and their friend Sia, an activist who refuses to conform to dominant norms of femininity. They all struggle to find space and happiness in a conservative Indian city. It is a same-sex love story but it is not limited to that; it explores the question of freedom of expression and women's rights in India. The film was premiered at BFI Flare in March 2016, and it is in the festival circuit right now. For about a year now we have been trying for our film KaBodyscapes to get certified by the CBFC and release it for an Indian audience.

The film was first submitted to the CBFC in Thiruvananthapuram in April last year, but they refused to certify it, as did the Revising Committee in Chennai in July 2016. I then approached the High Court in Kerala, where the judge required the $\mathrm{CBFC}$ to certify the film within 30 days. However, the $\mathrm{CBFC}$ chose to ignore the judgement at first and later filed an appeal, stating that a bench should have addressed the case with more than one judge. In December 2016, the two-judge bench dismissed that appeal and required them to certify the film within 90 days. But that too was overlooked by the CBFC. The Second Revising Committee, headed by CBFC chairperson 
Pahlaj Nihalani, again refused the film a certification on 17 February 2017, in Mumbai. If approaching the Supreme Court of India is what it takes, then we will approach the Supreme Court of India.

JMB: Has living outside India enhanced your status as an engaged film director, being involved in what is called in French, cinéma engagé? Has it even forced you into this status? Is this perception wrong, or exaggerated?

JC: It is not a conscious effort to make cinéma engagé. In the small Kerala village where I was born and brought up, caste is practised beyond religious boundaries. Christians and Muslims practise and enforce caste as much as any upper-caste Hindu does. Papilio Buddha was my first feature film and I wanted to tell a story that is close to my life. As I stated before, I wrote this film based on real events and chose actors whose lives revolve around the Dalit land rights movement in Kerala. Living outside India has probably enabled me to look into my culture and society from outside and approach it more critically.

NT: You refer to yourself as "caste queer". Could you tell us a bit more what this means to you? Is this stance related to the term "Dalit", or do you see it as related?

JC: What I mean by "caste queer" is a person who does not subscribe to any caste identity and refuses to conform to any social identity forced upon them by birth. "Caste" is intrinsically oppressive and any form of caste practice is insane; I personally reject the caste system, which is rooted in Hindu Dharmashastras that legitimatizes the doctrine of Chaturvana. As Babasaheb Ambedkar explains in his Annihilation of Caste, "Caste has killed the public spirit. Caste has destroyed the sense of public charity. Caste has made public opinion impossible. A Hindu's public is his caste. His responsibility is to his caste. His loyalty is restricted only to his caste. Virtue has become caste-ridden, and morality has become caste-bound" (2008: 29). It is one of the most dangerous tools of oppression that ever human beings have invented. So I like to call myself a "caste queer".

JMB: You are a poet and a writer just as much as a filmmaker, maybe even more so. How do you work across these media? And what does film do that literature doesn't do to translate the Dalit struggle? Can you say something about your choice of these different media?

JC: $\quad$ Writing poetry and making cinema are similar to me; in both we are telling the story through images. My cinema is an extension of my poems, but the process is fundamentally different. Writing is a very personal experience, like masturbation. On the other hand, making a film is a collective expression: there are a lot of artists involved. It is a joint effort, huge money is involved, a harmonious coordination of the various departments is essential; it is like an orgy, you have to make sure everyone "comes" together. Literature is a powerful medium, but I think a film can communicate with more people simultaneously, the experience of watching a movie in a theatre or an auditorium is a collective act, and it is unique. I don't think it is doing anything with the Dalit struggle in particular, but activists around the 
world have used visual narratives widely as an organizing tool. As I am involved more deeply in filmmaking, the frequency of my writing poems is getting lower and lower. As my films are often dragging me into trouble, economically and socially, I need greater peace of mind to sit down and write poems.

JMB: Would you care to put in a few words about who you film for? Is there a difference between the intended audience and the real audience?

JC: I am making films for the cinephiles around the world, but my primary audience will be people of Kerala, who speak Malayalam, and the people of India. Unfortunately, the CBFC has denied the certificate for two of my films in a row, which makes it difficult for me to take the films to my intended audience. Still, we are finding alternative venues of distribution, such as private screenings and online distribution. I am optimistic, in the near future, that the censorship laws will be changed, and state intervention in filmmaking will be ended in India. There are several filmmakers, and those within civil society, who are fighting for a better India where an artist can express themselves freely and exhibit their work in public without any government permission. I will keep on making the films I want to make, and share with the audience who care to watch them, no matter what part of the world they live in.

\section{Bibliography and filmography}

Ambedkar BR (2008) Annihilation of Caste. Delhi: Gautam Bookcenter.

Ambedkar BR (1945) What Congress and Gandhi Have Done to Untouchables. Available at: http://guruprasad.net/wp-content/uploads/2014/06/What-Congress-and-Gandhi-have-doneto-the-Untouchables.pdf (accessed 30 April 2017).

Cherian JK (dir.) (2010) Shape of the Shapeless [Film]. Perf. Rose Wood, Helen Moschetti, Glenn Marla. New York, NY: Inner Silence Films.

Cherian JK (dir.) (2013) Papilio Buddha [Film]. Perf. Kallen Pokkudan, Sreekumar SP, David Briggs. Thiruvananthapuram, India: Kayal Films and Silicon Media.

Cherian JK (dir.) (2016) KaBodyscapes [Film]. Perf. Jason Chacko, Rajesh Kannan, Naseera NM. Thiruvananthapuram, India: Inner Silence Films.

Cherian JK (1996) Ayodhanathinte Achuthandu. Kozhikodu, Kerala: Mulberry Books.

Cherian JK (1999) Ayanam Vachana Rekhayil. Kozhikodu, Kerala: Mulberry Books.

Cherian JK (2001) Polymorphism. Kozhikodu, Kerala: Mulberry Books.

Cherian JK (2006) Pachakku. Thrissur, Kerala: Current Books.

Pokkudan K (2002) Kandal Kaadukalkkidayil Ente Jeevitham (My Life in the Mangrove Forests). Kottayam, Kerala: DC Books.

Pokkudan K (2010) Ente Jeevitham (My Life). Kottayam, Kerala: DC Books.

Pokkudan K (2015) Kandal Inangal (Mangrove Varieties). Thrissur, Kerala: Green Books. 